\title{
CONTROL OF THE INTELLIGENCE AGENCIES
}

\author{
Thomas I. Emerson $\dagger$
}

The existence of modern intelligence agencies presents a critical dilemma for any democratic society. The term "intelligence agency," as used here, does not refer to ordinary police forces investigating traditional crime or administrative agencies seeking to enforce regulatory measures. Rather it designates agencies, such as the Federal Bureau of Investigation (FBI), the Central Intelligence Agency, the National Security Agency, and the intelligence services of the armed forces, that seek to collect a broad range of information for use by the government, including information relating to the political opinions and activities of various targeted individuals and groups. The development of such agencies in the United States is, at least on the present scale, a relatively new phenomenon. Normal democratic controls designed to prevent abuses in the exercise of official authority have not caught up with this form of government activity.

Not only is the problem a critical one but its solution raises unique difficulties. This is apparent from an examination of the basic principles upon which intelligence institutions operate. The most fundamental condition for success of an intelligence agency is secrecy. Virtually all that goes on within the agency is withheld from public view. A second characteristic is the insatiable scope of the intelligence agency's interest. Under the "mosaic theory," almost anything is grist for its mill as it seeks to collect information on beliefs, opinions, associations, and actions in ever-widening circles. Third, the intelligence agency is under pressure to use highly intrusive methods for collecting information. The data it seeks may be available only through the employment of wiretapping, bugging, break-ins, informers, and infiltrators, and may entail overlooking or engaging in outright violations of law. Finally, there

$\dagger$ A.B., Yale University, 1928; LL.B., Yale Law School, 1931. Lines Professor of Law Emeritus, Yale Law School. Author of Toward a General Theory op the First Amendment (1966); The System of Freedom of Expression (1970); Political and Civil Rights in the United States (with D. Haber \& N. Dorsen) (4th ed. 1976). 
develops a strong bureaucratic temptation to move from the collection of information to "preventive action," that is, affirmative interference with the political process. In doing so, the agency tends to take upon itself the function of administering punishment, without due process of law, and in the end may become an instrument for policy formation.

It is evident that these characteristics of an intelligence agency are diametrically opposed to the basic principles of a democratic polity. In the proper functioning of a democratic society, government operations should be open, and information about government activities should be available to the general public. Under the first amendment, governmental conduct should not impinge upon beliefs, opinions, or associations until the stage of overt illegal action has been reached. Under the fourth amendment and other constitutional requirements, methods of investigation are strictly controlled and official violation of law never sanctioned. The rule of law demands that official punishment be imposed upon political activities only by properly elected or delegated authority.

These theoretical contradictions between the principles of a democratic society and the imperatives of intelligence operations have been manifested in actual experience. The post-Watergate exposures revealed an alarming state of affairs. Taking the FBI alone, it appeared that the agency had conducted lengthy investigations into political activities where there was no suggestion that any law had been violated. In the course of those activities, the FBI had accumulated voluminous dossiers on hundreds of thousands of citizens. It employed thousands of informers, engaged in widespread wiretapping and bugging, conducted illegal breakins, and participated in other forms of unlawful conduct. In addition, the FBI, through its Cointelpro and other programs, had carried on extensive harassment of the targets of its investigations. In doing so it had utilized such tactics as securing discharge from employment, disrupting meetings, writing poison-pen letters, engaging in forgery, and encouraging violence.

This is not to say that the intelligence agencies should be abolished. Investigation of political crimes, counterintelligence, the collection of information that does not encroach on individual rights are all legitimate functions of such agencies. But past experience does make starkly clear that operations of the intelligence agencies must be brought within the democratic system. The recent devel- 
opment of information technology, with the consequent creation of networks of data banks, makes this even more imperative today.

As Americans began to assess the implications of the Watergate revelations, it became immediately apparent that there was a serious absence of controls over the activities of the intelligence agencies. No specific statutory provisions govern the scope of their authority or their methods of operation. Executive Orders and internal guidelines establish some limits but are both inadequate in substance and subject to revocation at will. Constitutional protections of course are available, but reliance upon these guarantees entails lengthy litigation, and the constitutional picture has been clouded by government claims that constitutional requirements do not apply in matters involving national security or the conduct of foreign relations. The need, therefore, is for some concrete legislation that expressly addresses these pressing issues.

Following extensive investigations conducted in 1975 and 1976 by the Senate Select Committee under Senator Frank Church and the House Intelligence Committee headed by Representative Otis Pike, various bills to regulate the intelligence community were introduced in Congress. One of these, H.R. 6051, introduced in 1977, contained a comprehensive set of controls drafted by a group of civil liberties organizations including the American Civil Liberties Union. With the exception of the Foreign Intelligence Surveillance Act of 1978, regulating electronic surveillance in the foreign intelligence area, and the Intelligence Identities Protection Act of 1982, making it a criminal offense to disclose any information identifying a covert agent engaged in foreign intelligence, no action has been taken. Although the pressures for reform diminish as Watergate recedes into the background, efforts to obtain legislation ought not be abandoned.

The principles upon which legislative reform should be based derive from past experience. They may be stated briefly:

First, "preventive actions" in domestic intelligence investigations and "covert actions" abroad should be prohibited. The first violates rights under the American Constitution, and the second is inconsistent with the principles of international law.

Second, collection of information in the United States, and with respect to American citizens abroad, that involves the legitimate political activity of any person or group should be prohibited, except where it is directly and immediately related to the commis- 
sion of a crime or to the administration of a valid regulatory measure. This means, for instance, that the FBI, the main federal agency for criminal investigation, can institute an inquiry only when it has reason to believe, based on identifiable and articulated facts, that a federal crime has been, is being, or is about to be committed. The collection by government of data pertaining to the exercise of first amendment rights is plainly inhibiting and violates that constitutional guarantee.

Third, the retention, storage or dissemination of data relating to first amendment activities, except as necessary for legitimate law enforcement, should be prohibited.

Fourth, certain types of intrusive investigative methods, such as break-ins, mail opening, and the illegal use of electronic devices should be outlawed. The use of informers to infiltrate legitimate political groups should also be forbidden or, if necessary to a criminal investigation touching on first amendment activity, should require a judicial warrant.

Fifth, measures to assure official accountability, such as requiring that important decisions be recorded in writing and justified by findings of fact and reasons, should be established. Likewise, a system of internal supervision, and provision for external oversight, preferably by some agency such as the General Accounting Office, should be mandated.

Sixth, the controls should be enforced by criminal and civil penalties, including the right of persons adversely affected to bring suits for injunction and damages.

Control over the intelligence agencies is not easily accomplished. The investigatory process, where the relevancy of information cannot be established in advance, is not readily contained. The degree of necessary secrecy makes monitoring difficult. The legislatures, the courts and the public generally are too quickly persuaded that matters involving "national security" should be left to the executive officials of government. Efforts to establish controls by legislation may backfire, in that the only result may be the legitimation of formerly illegal or highly dubious forms of conduct. On the other hand, the risks of failure to act are high. The future of our democratic system may turn on what we do. 